\title{
Clustering of Large Bedrock Landslides and Recurrent Slope Failure: Implications for Land Seismic Hazard Assessment of the Tien Shan - Djungaria Region
}

\author{
Alexander Strom* \\ Geodynamics Research Center - Branch of JSC Hydroproject Institute, Moscow, Russia
}

\begin{abstract}
Spatial distribution of bedrock landslides in the Tien Shan - Djungaria mountain system is analyzed based on an inventory including more than 700 features, most of which are prehistoric and exceed $10^{6} \mathrm{~m}^{3}$ in volume. They often concentrate within limited areas several tens of kilometres in size, forming clusters divided by areas without or with very rare same-size slope failures. Two main types of landslide clusters are exemplified by case studies from the Chinese and Kazakh parts of this mountain system: those that have one giant feature surrounded by numerous much smaller landslides and those that include several more or less same-size features. Though no data about ages of slope failures that formed these clusters are available, in some cases simultaneity of their formation can be assumed with reasonable confidence. Besides, evidence of recurrent slope failure within these areas is presented. Considering arid climate of the region and limited glaciation, large earthquakes are the most likely trigger of such spatially and temporally localized slope failures, though additional studies are necessary to prove this assumption. In any case landslide and, likely, seismic hazard of such zones seem to be higher than that of the surrounding rockslide-free areas.
\end{abstract}

Keywords: bedrock landslide, rock avalanche, cluster, Tien Shan, Djungaria, earthquake, hazard assessment

\section{Introduction}

The Tien Shan - Djungaria mountain system that extends for about $2000 \mathrm{~km}$ from west to east and up to $500 \mathrm{~km}$ from north to south is characterized by high neotectonic and seismic activity. Besides, more than 700 large-scale rockslides exceeding $10^{6} \mathrm{~m}^{3}$ in volume have been identified there (Figure 1). Most of them are prehistoric. As for the historical rockslides, the majority of them were triggered by large earthquakes - the 1887 M7.3 Verniy (Mushketov 1890), the 1911 M8.2 Kemin (Bogdanovich et al 1914, Delvaux et al 2001), the 1946 M7.5 Chatkal (Leonov 1970), the 1949 M7.4 Khait (Leonov 1960, Evans et al 2009b), and the 1992 M7.3 Suusamyr (Korjenkov et al 2004). However, at least one such event, i.e. the 1964 Aini landslide, occurred without evident trigger (Fedorenko 1988, Neshikhovskiy 1988, Strom 2013). Considering this case study and the fact that bedrock landslides are distributed within the Tien Shan much wider than large historical earthquakes (Figure 1), the correct interpretation of their origin (triggering factors) is critical for reliable assessment of both landslide and seismic hazard (Strom 2013).

Analysis of spatial distribution of large-scale bedrock landslides both in the Tien Shan and in other mountainous systems shows that they usually occur not uniformly over the entire range with more or less similar geological and geomorphic characteristics (rock types, tectonic

*Corresponding Author: Alexander Strom, email: strom.alexandr@yandex.ru; Tel: +7 (910)-455-4305 


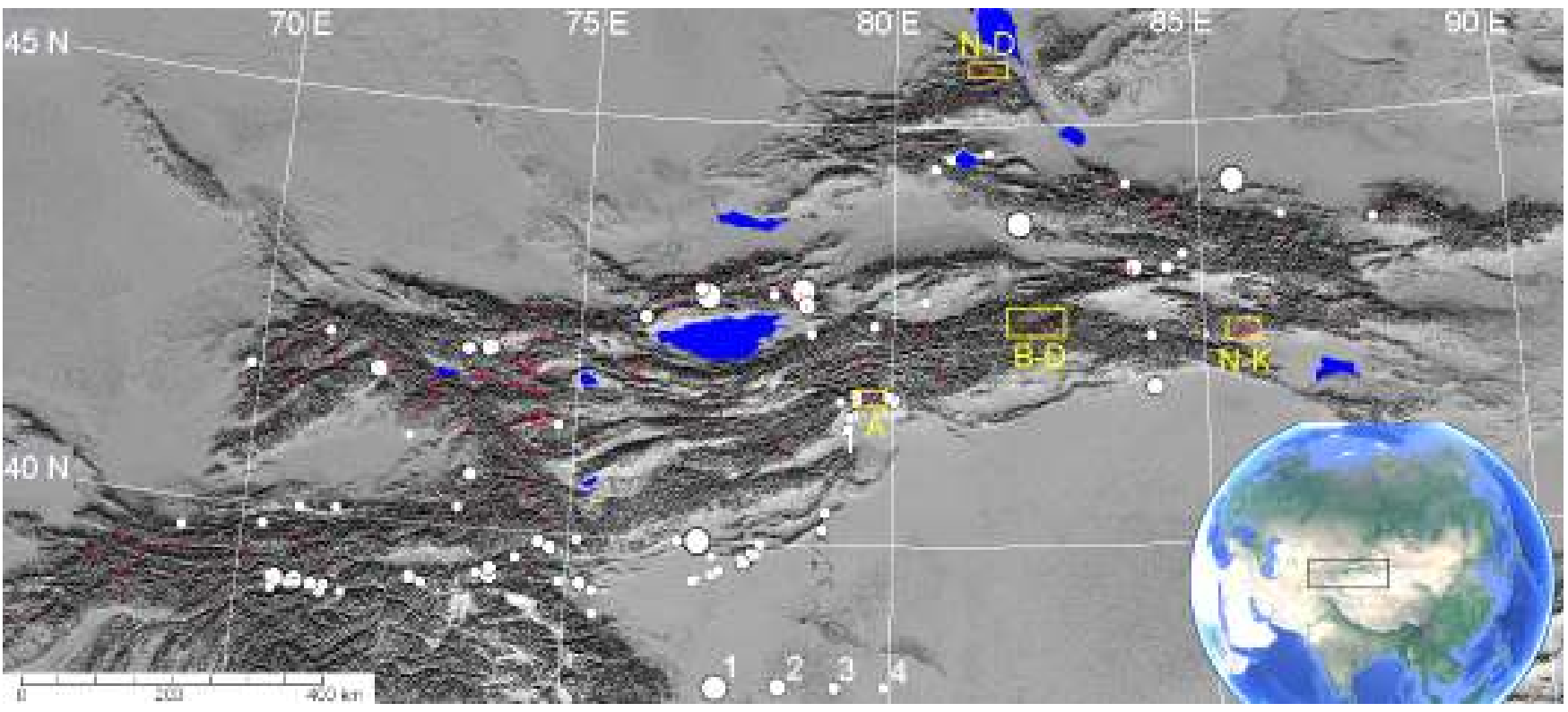

Figure 1. Spatial distribution of large-scale bedrock landslides (pink dots) and large $(M>6)$ earthquakes in the Tien Shan Djungarian mountain system. 3" STRM DEM is a background. Location of the study area is marked on the inset. Yellow rectangles outline landslide clusters described in details: (A) Aksu, (B-D) Big Dragon Lake, (N-K) Northern-Kaidu, (N-D) Northern-Djungaria. Earthquake epicentres: (1) $\mathrm{M}>7.5$, (2) $\mathrm{M}=7.1$ - 7.5, (3) $\mathrm{M}=6.6-7.0$, (4) $\mathrm{M}=6$ - 6.5

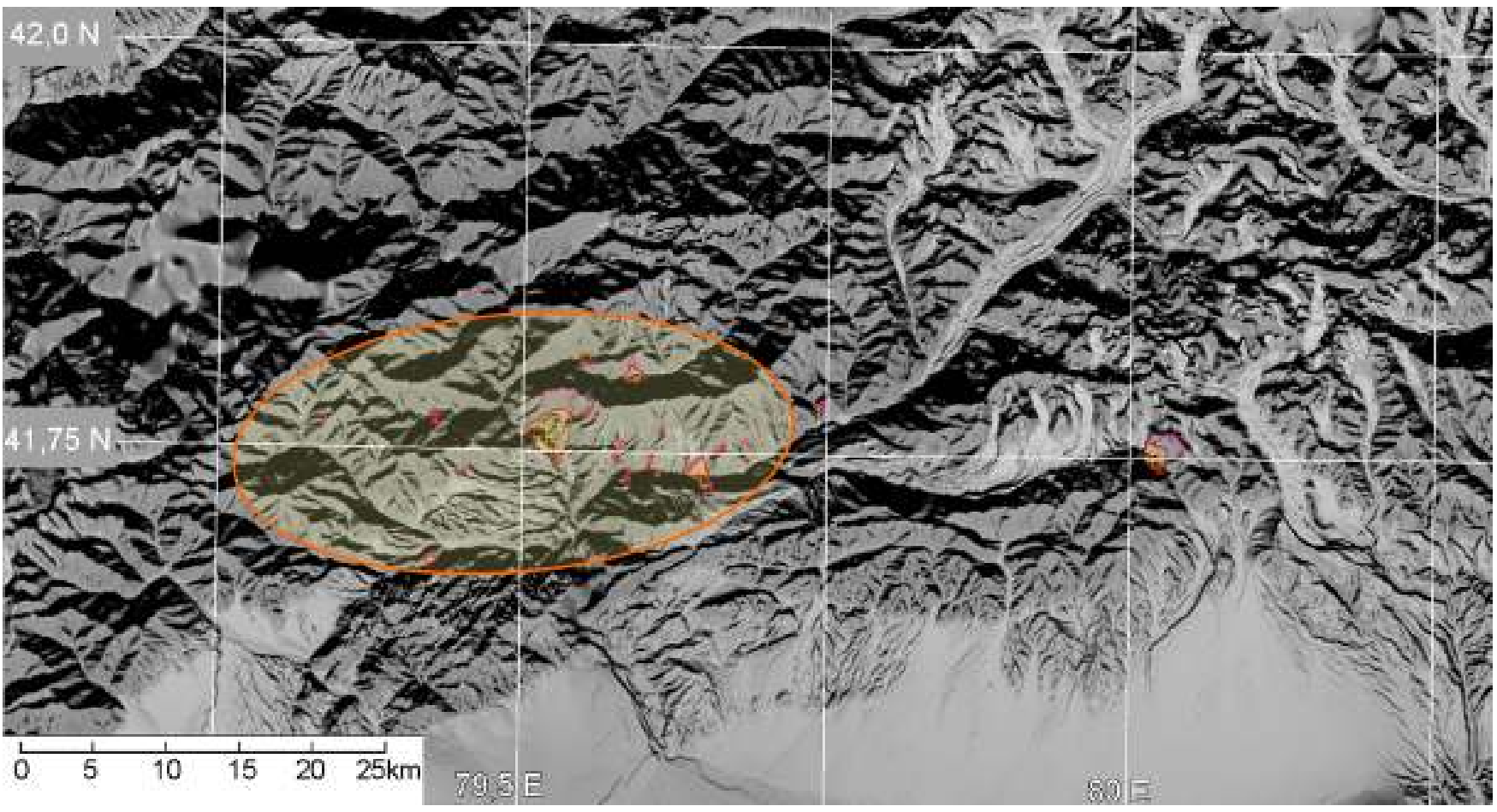

Figure 2. The bedrock landslides cluster in the lower reaches of the Aksu River basin (marked by orange oval). Pink lines headscarps, crosshatched areas - landslide bodies.

structure, slopes' height and steepness, etc.), but concentrate at some localized zones or 'knots' where rocky slopes fail simultaneously and/or repeatedly. Such irregularity is well expressed in the Kyrgyz part of the Tien Shan (Strom and Abdrakhmatov 2004). Similar rockslide distribution was found within the entire Tien Shan - Djungaria mountainous system. Several 
examples of such clustering from the Chinese Tien Shan and from the Kazakh part of the Djungaria mountains are described hereafter.

\section{Types of Landslide Clusters}

Two main types of bedrock landslide clusters can be defined. Clusters of the first type ('core' clusters) include one or few gigantic rockslides surrounded by numerous much smaller features. Clusters of the second ('uniform') type are formed by several more or less same-size features. I want to point out that, since we deal with prehistoric events that had occurred many hundreds and thousands years ago, most of slope failures less than $\sim 10^{5} \mathrm{~m}^{3}$ in volume do not preserve in landscape for such a long time and have not been mapped and included in the inventory. Thus, 'smaller' features are 'small' just in comparison with the 'core' landslide(s), while some of them, millions and even tens of millions cubic meters in volume, being treated themselves alone could be classified as large slope failures.

\section{1 'Core' clusters}

Good example of such cluster could be found in the lower reaches of the Aksu River valley (upstream in Kyrgyzstan is named the Sarydjaz River) (Figure 2). The core member of this $30 \mathrm{~km}$ long and $10 \mathrm{~km}$ wide cluster is a $300 \mathrm{~m}$ high breached rockslide dam, about $900 \times 10^{6} \mathrm{~m}^{3}( \pm$ $30 \%$ ) in volume with distinct traces of the powerful outburst flood that had painted river terraces up to $120 \mathrm{~m}$ high by black debris eroded from the dam's body (Figure 3). Considering the level at which outburst flood passed through, the discharge was comparable with that of the 1985 Bairaman (Papua New Guinea) rockslide dam breach (King et al 1989). This gigantic feature is surrounded by more than 20 rockslides, whose volumes are 1.5 - 3 orders less than that of the core one (Table 1).

No similar feature has been found up to several tens of kilometers around this cluster, except one large rockslide $\sim 25 \mathrm{~km}$ east from it (Figure 2), despite the erosion pattern, depth of river valleys, etc., within and outside the cluster area look similar. Nothing exceptional could be found here in the geological structure too.
Nevertheless, bedrock landslides concentrate within this limited area only.

Table 1. Basic parameters of the Aksu cluster landslides

\begin{tabular}{rrrrrr}
\hline & Lat & Lon & $\begin{array}{c}\text { Area of } \\
\text { the } \\
\text { No } \\
\end{array}$ & $\begin{array}{c}\text { Total } \\
\text { area } \\
\text { deposits } \\
\left(\mathrm{km}^{2}\right)\end{array}$ & $\begin{array}{c}\text { Volume } \\
\text { affected } \\
\left(\mathrm{km}^{2}\right)\end{array}$ \\
\hline 1 & 41.7641 & & \\
\hline 2 & 41.7686 & 79.5262 & 7.150 & 10.13 & 900 \\
\hline 3 & 41.8071 & 79.5506 & 0.280 & 0.50 & 5 \\
\hline 4 & 41.7957 & 79.5902 & 0.970 & 1.27 & 17 \\
\hline 5 & 41.7347 & 79.4495 & 0.026 & 0.03 & 0.13 \\
\hline 6 & 41.7717 & 79.4283 & 0.050 & 0.09 & 0.25 \\
\hline 7 & 41.7717 & 79.4259 & 0.100 & 0.19 & 0.5 \\
\hline 8 & 41.7717 & 79.4317 & 0.087 & 0.19 & 0.45 \\
\hline 9 & 41.7366 & 79.5885 & 0.140 & 0.26 & 1.5 \\
\hline 10 & 41.7375 & 79.6120 & 0.080 & 0.11 & 1 \\
\hline 11 & 41.7555 & 79.6829 & 0.041 & 0.08 & 0.5 \\
\hline 12 & 41.7448 & 79.6058 & 0.190 & 0.25 & 3 \\
\hline 13 & 41.7395 & 79.6532 & 0.050 & 0.06 & 0.4 \\
\hline 14 & 41.7403 & 79.6454 & 1.21 & 1.41 & 50 \\
\hline 15 & 41.7319 & 79.6500 & 0.680 & 0.94 & 12 \\
\hline 16 & 41.6816 & 79.4270 & 0.264 & 0.35 & 7 \\
\hline 17 & 41.7359 & 79.4530 & 0.050 & 0.09 & 0.3 \\
\hline 18 & 41.7740 & 79.5527 & 0.200 & 0.27 & 1 \\
\hline 19 & 41.7728 & 79.5611 & 0.030 & 0.05 & 0.1 \\
\hline 20 & 41.7626 & 79.613 & 0.07 & 0.18 & 0.2 \\
\hline 21 & 41.7542 & 79.583 & 0.11 & 0.16 & 1.5 \\
\hline 22 & 41.7457 & 79.5774 & 0.09 & 0.20 & 1 \\
\hline 23 & 41.7787 & 79.7445 & 0.2 & 0.26 & 4 \\
\hline & & & & & 17 \\
\hline
\end{tabular}

Similar distribution is typical for the $\sim 100 \mathrm{~km}$ long cluster that includes one of the largest bedrock slope failures of the Chinese Tien Shan the Big Dragon Lake rockslide, about $2.0 \mathrm{~km}^{3}$ in volume (Figure 1 and Table 2). The density of slope failures in this cluster is lower than that in the Aksu, but, similarly, no one bedrock rockslide larger than $\sim 10^{6} \mathrm{~m}^{3}$ in volume was identified in the surrounding mountains closer than $\sim 50 \mathrm{~km}$ from the failure at the end of the cluster.

Such distribution - one gigantic landslide surrounded by much smaller features - was described by Malamud et al (2004) as being typical of landslides triggered by highly energetic triggering events such as large earthquakes and 
typhoons. Since no data about ages of slope failures that formed these clusters are available, it is unknown if they occurred simultaneously or not.

Table 2. Basic parameters of the Big Dragon Lake cluster landslides

\begin{tabular}{|c|c|c|c|c|c|}
\hline No & $\begin{array}{c}\text { Lat } \\
\text { (dd.dddd) }\end{array}$ & $\begin{array}{c}\text { Lon } \\
\text { (dd.dddd) }\end{array}$ & $\begin{array}{c}\text { Area of } \\
\text { the } \\
\text { deposits } \\
\left(\mathrm{km}^{2}\right)\end{array}$ & $\begin{array}{c}\text { Total } \\
\text { area } \\
\text { affected } \\
\left(\mathrm{km}^{2}\right) \\
\end{array}$ & $\begin{array}{l}\text { Volume } \\
\left(10^{6} \mathrm{~m}^{3}\right)\end{array}$ \\
\hline 6 & 42.6086 & 82.3942 & 9.5 & 14.72 & 2000 \\
\hline 2 & 42.6053 & 82.0819 & 0.66 & 0.67 & 8 \\
\hline 3 & 42.5976 & 81.6384 & 0.180 & 0.39 & 1.5 \\
\hline 5 & 42.6084 & 81.9995 & 0.673 & 0.95 & 10 \\
\hline 1 & 42.6053 & 82.0819 & 1.57 & 1.60 & 25 \\
\hline 8 & 42.6617 & 82.1784 & 0.32 & 0.38 & 4 \\
\hline 9 & 42.7942 & 82.7075 & 0.077 & 0.16 & 0.2 \\
\hline 11 & 42.569 & 81.5939 & 0.387 & 0.46 & 3 \\
\hline 7 & 42.7068 & 82.4764 & 0.111 & 0.15 & 1 \\
\hline 4 & 42.5411 & 81.9359 & 0.333 & 0.37 & 0.7 \\
\hline 10 & 42.7403 & 82.6423 & 0.050 & 0.07 & 0.15 \\
\hline
\end{tabular}

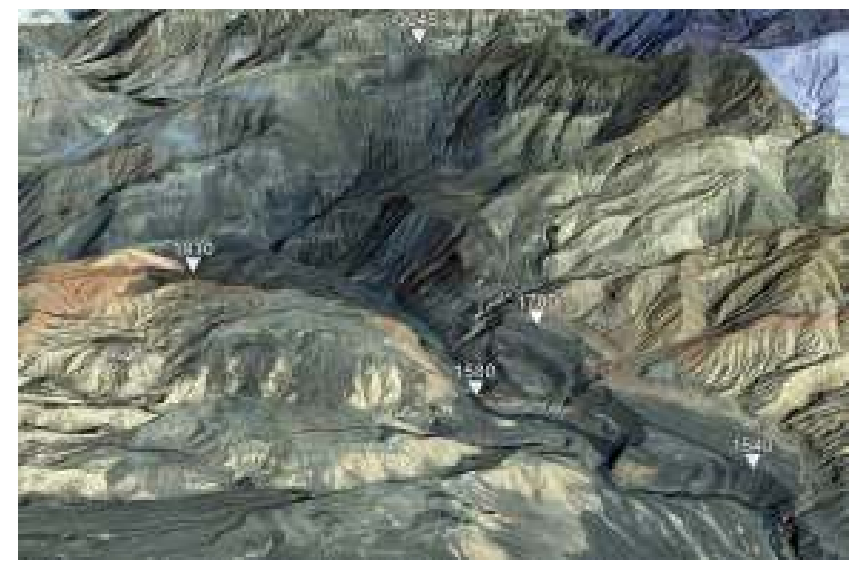

Figure 3. Gigantic breached rockslide dam in the Aksu River valley with outburst flood traces. Numbers show altitudes of the specific geomorphic features (headscarp crown, tip of the rockslide deposits, stream and terraces just downstream from the dam). 3D Google Earth image

\section{2 'Uniform' clusters}

Clusters of this type include large number of bedrock landslides with much smaller variety of volumes and lack of 'super-large' features. Such group of rockslides was found in the mountain ridge north from the Kaidu River that flows from west to the Bosten Lake (Figure 1). About 20 rockslides and rock avalanches have been identified here within a limited area of about $30 \times$ $10 \mathrm{~km}$ (Table 3), while nearest similar features were mapped more than $40-50 \mathrm{~km}$ far from it (Figure 4).

Interesting peculiarity of this Northern-Kaidu cluster is that at least two generations of landslides can be distinguished here (Figure 5) 12 younger, likely Late Holocene rockslides and rock avalanches (Figure 6), and several older and poorly defined, likely Late Pleistocene rockslides (Figure 7), some of which are much larger than those more recent events (Table 3 ).

Though no accurate ages of any of these features are available, freshness and similar expressiveness of recent generation of rockslides in the landscape (Figure 6) allow rather wellgrounded assumption of their real simultaneity.

Numerous rockslides and rock avalanches varying in size within 1 - 1.5 orders of magnitude, many of which have dammed small lakes, have been found in Southern Kazakhstan, in the northern part of the Djungaria mountains - the northern branch of the Tien Shan mountain system (Figure 1). They group in several clusters, two of which (Table 4) can be seen in Figure 8. Couples of the nearby rockslides that, likely occurred simultaneously, were identified within these clusters. Such conclusion can be drawn based on similar expressiveness of rockslide headscarps and deposits in the landscape (Figure 9) and on mutual position of rockslide bodies that do not overlap one another but rest side-by-side (Figure 10), which could only occur if they failed simultaneously.

\section{Discussion}

Rockslide clusters of both types demonstrate peculiarities allowing assumption on the prevailing role of seismicity in their formation. It should be pointed out that arid climate of the study region constrains possibility of rainstorms to be an important triggering factor of large-scale bedrock slope failures.

Since in the Tien Shan and Djungaria Mountains, most of the rockslides were identified at the medium elevation levels, often outside 
present and former glaciated zones, the glacial retreat, slopes debuttressing and mountain permafrost degradation could not influence the bedrock slopes instability significantly, as it was proposed for the Alps (Crosta et al 2013) and could be assumed for the world's largest 'megacluster' of gigantic bedrock landslides in the
Indus River basin in Karakorum (Hewitt 1998, 2002, 2006, 2011, 2015).

With this in mind the assumption of seismic triggering for rockslides forming the 'uniform' clusters is supported by their likely simultaneity.

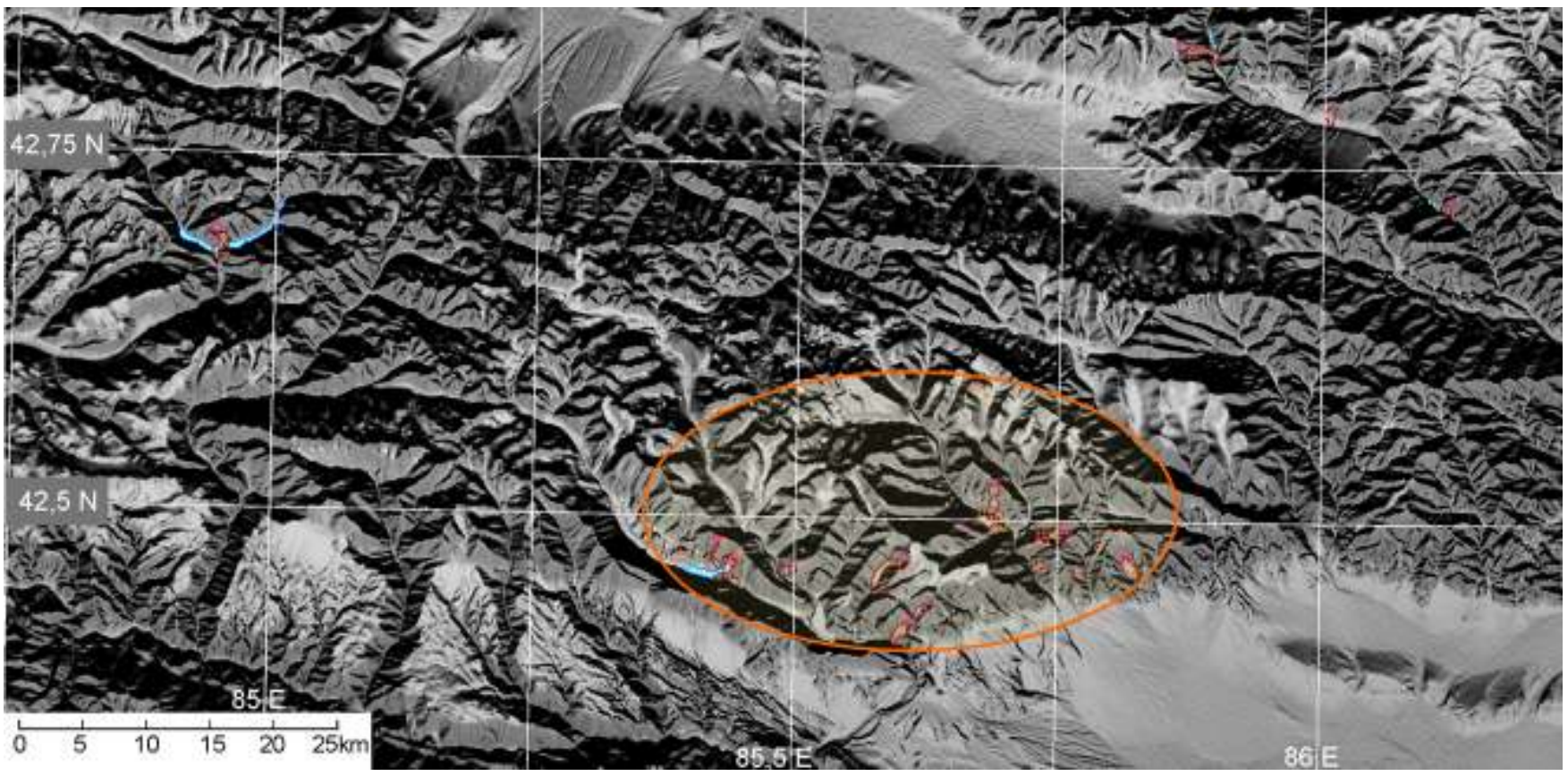

Figure 4. The Northern-Kaidu landslide cluster (marked by orange oval). Large landslides outside this cluster are about 40-50 $\mathrm{km}$ far from it (see Fig. 5 for legend)

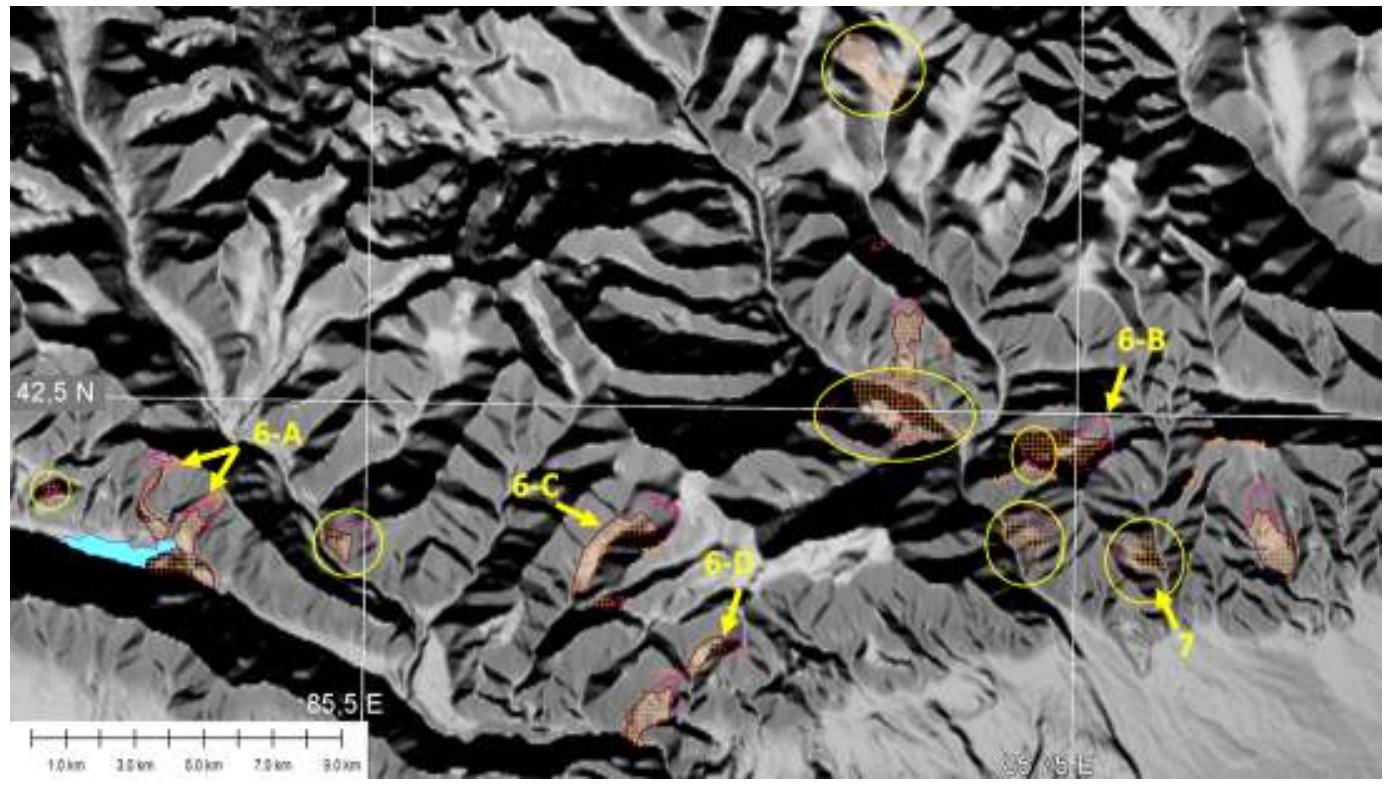

Figure 5. More detailed map of the Northern-Kaidu landslide cluster. Pink lines - headscarps, solid - well-defined, dashed poorly defined, cross-hatched areas with brown boundaries - distinct landslide bodies, those without boundaries - poorly identified, comb orange lines - evidence of the deep-seated gravitational slope deformations (DSGSD); blue areas landslide-dammed lakes. Much older features are marked by yellow circles and ovals. Yellow arrows indicate features shown on Figures 6 A-D and 7 
Table 3. Basic parameters of the Big Northern-Kaidu cluster landslides

\begin{tabular}{|c|c|c|c|c|c|}
\hline No & $\begin{array}{c}\text { Lat } \\
\text { (dd.dddd) }\end{array}$ & $\begin{array}{l}\text { Lon } \\
\text { (dd.dddd) }\end{array}$ & $\begin{array}{l}\text { Area of } \\
\text { the } \\
\text { deposits } \\
(\mathrm{km} 2)\end{array}$ & $\begin{array}{c}\text { Total } \\
\text { area } \\
\text { affected } \\
(\mathrm{km} 2)\end{array}$ & $\begin{array}{l}\text { Volume } \\
\text { (106m3) }\end{array}$ \\
\hline \multicolumn{6}{|c|}{ Younger generation } \\
\hline 1 & 42.4707 & 85.4232 & 1.030 & 1.37 & 10 \\
\hline 2 & 42.4609 & 85.4368 & 1.930 & 2.38 & 40 \\
\hline 3 & 42.4665 & 85.5878 & 1.660 & 2.52 & 60 \\
\hline 4 & 42.4487 & 85.5861 & 140 & 0.26 & 0.3 \\
\hline 5 & 42.4370 & 85.6208 & 0.560 & 0.79 & 9 \\
\hline 6 & 42.4202 & 85.6010 & 1.245 & 1.68 & 30 \\
\hline 7 & 42.5146 & 85.6891 & 1.625 & 1.97 & 20 \\
\hline 8 & 42.4911 & 85.7497 & 0.910 & 1.22 & 15 \\
\hline 9 & 42.5435 & 85.6809 & 0.035 & 0.09 & 0.35 \\
\hline 10 & 42.4680 & 85.8190 & 1.530 & 2.00 & 40 \\
\hline 11 & 42.5001 & 85.6909 & 0.120 & 0.36 & 3.5 \\
\hline 12 & 42.4905 & 85.7511 & 1.040 & 1.42 & 15 \\
\hline \multicolumn{6}{|c|}{ Older generation } \\
\hline 1 & 42.4632 & 85.7757 & 1.000 & 1.70 & 200 \\
\hline 2 & 42.5006 & 85.6829 & 3.660 & 5.50 & 250 \\
\hline 3 & 42.4692 & 85.7320 & 1.200 & 1.60 & 200 \\
\hline 4 & 42.4634 & 85.4923 & 0.500 & 1.10 & 15 \\
\hline 5 & 42.5898 & 85.6759 & 1.610 & 1.80 & 10 \\
\hline 6 & 42.4755 & 85.3885 & 0.107 & 0.14 & 0.3 \\
\hline 7 & 42.4914 & 85.7369 & 0.663 & 0.87 & 11 \\
\hline
\end{tabular}

Similar landscape expressiveness of numerous nearby features as in the NorthernKaidu cluster (Figure 6) and in the western part of the Northern-Djungaria cluster (Figure 9) indicates high probability of real-time simultaneous formation of rockslides forming each of these clusters. This, in turn, allows assumption that slope failures in each cluster were triggered by large earthquakes.

For the 'core' clusters, it is less evident though they correspond better to the size distribution of landslides triggered by catastrophic natural phenomena (Malamud et al 2004). Though actual data on the ages of both gigantic 'core' rockslides and their 'satellites' are missing, we can assume that they could occur simultaneously. Sometimes their seismic triggers can be proved with reasonable confidence by the joint analysis of various indirect evidence as in the case of the Kokomeren rockslide (Strom and Stepanchikova 2008, Strom 2012).

For the Northern-Djungaria cluster it can be proved by the presence of rockslide bodies resting side-by-side (Figure 10). Similar phenomena can be observed at the Bielogorka 'twin' rockslides at $42.635^{\circ} \mathrm{N}, 74.287^{\circ} \mathrm{E}$, not far from the Bishkek City (Havenith et al 2003).

An important characteristic feature of both types of clusters is the recurrent slope failure during Late Pleistocene - Holocene time (confident identification of older landslides is questionable). Repeated formation of rockslides triggered either by large earthquakes or by other phenomena on the same or nearby slopes was reported worldwide.

Table 4. Basic parameters of the Northern Djunraria clusters landslides

\begin{tabular}{|c|c|c|c|c|c|}
\hline No & $\begin{array}{c}\text { Lat } \\
\text { (dd.dddd) }\end{array}$ & $\begin{array}{c}\text { Lon } \\
\text { (dd.dddd) }\end{array}$ & $\begin{array}{c}\text { Area of } \\
\text { the } \\
\text { deposits } \\
\left(\mathrm{km}^{2}\right)\end{array}$ & $\begin{array}{c}\text { Total } \\
\text { area } \\
\text { affected } \\
\left(\mathrm{km}^{2}\right)\end{array}$ & $\begin{array}{l}\text { Volume } \\
\left(10^{6} \mathrm{~m}^{3}\right)\end{array}$ \\
\hline \multicolumn{6}{|c|}{ Western cluster } \\
\hline 1 & 45.7205 & 78.3711 & 0.310 & 0.47 & 11 \\
\hline 2 & 45.6918 & 81.4242 & 0.680 & 1.03 & 25 \\
\hline 3 & 45.6577 & 81.4475 & 0.200 & 0.51 & 4 \\
\hline 4 & 45.6502 & 81.4626 & 1.724 & 2.33 & 50 \\
\hline 5 & 45.6934 & 81.4711 & 0.842 & 1.20 & 30 \\
\hline 6 & 45.6945 & 81.5007 & 0.564 & 0.80 & 10 \\
\hline 7 & 45.6468 & 81.3780 & 0.176 & 0.29 & 3 \\
\hline 8 & 45.6825 & 81.3732 & 0.530 & 0.76 & 8 \\
\hline 9 & 45.6593 & 81.3281 & 0.094 & 0.16 & 1.5 \\
\hline 10 & 45.6372 & 81.3475 & 0.213 & 0.50 & 5 \\
\hline 11 & 45.6276 & 81.3701 & 0.350 & 0.56 & 7 \\
\hline 12 & 45.6232 & 81.3739 & 0.170 & 0.23 & 2 \\
\hline \multicolumn{6}{|c|}{ Eastern cluster } \\
\hline 1 & 45.6410 & 82.0021 & 0.214 & 0.51 & 5 \\
\hline 2 & 45.6426 & 81.7955 & 0.484 & 0.82 & 10 \\
\hline 3 & 45.6462 & 81.8071 & 1.202 & 1.59 & 30 \\
\hline 4 & 45.5727 & 81.6933 & 0.121 & 0.21 & 2 \\
\hline
\end{tabular}




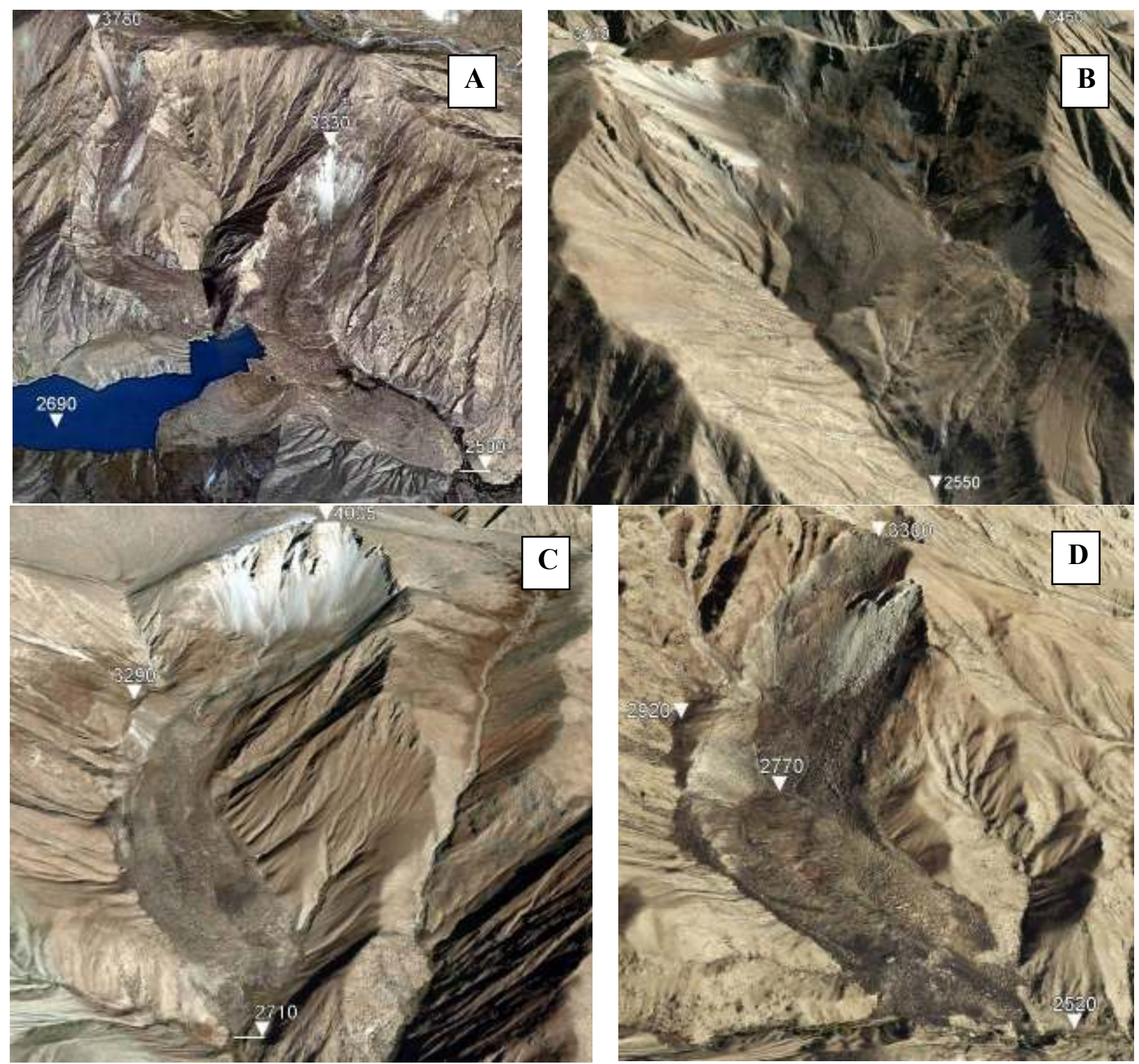

Figure 6. Recent rockslides and rock avalanches of the Northern-Kaidu cluster. Numbers show altitudes of the specific geomorphic features (headscarp crowns, tips of rockslide deposits, etc.). 3D Google Earth images

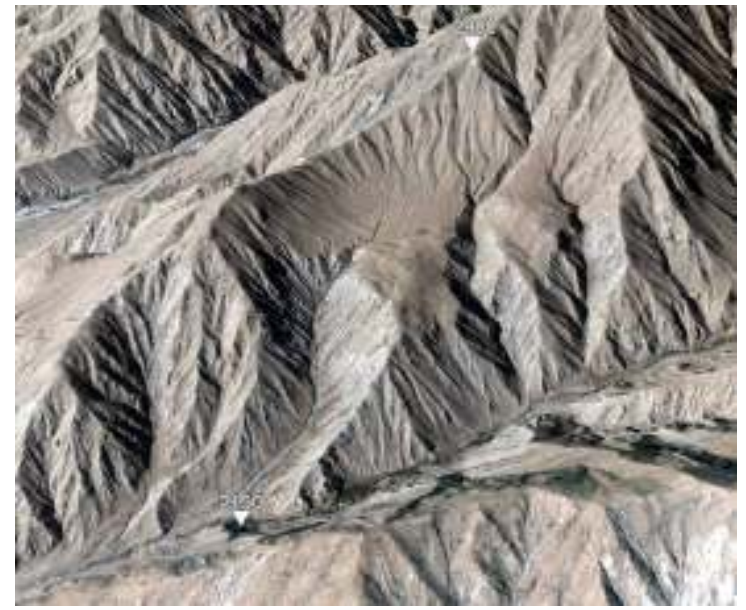

Figure 7. Old, likely Late Pleistocene, deeply eroded rockslide. 3D Google Earth image
It occurred in Peru where ice-rock avalanches collapsed from the Nevado Huaskaran in 1962 and 1970 (Plafker and Eriksen 1978) and evidence of similar or even larger past event(s) were found out as well (Evans et al 2009a). Large-scale slope failures from almost the same source occurred in Tibet in the Zhamulong Gully at least twice, in 1900 and in 2000, resulting in the Yigong river blocking and devastating outburst floods (Shang et al 2003, Delaney and Evans 2015). Recurrent past slope failures have occurred in the Flims-Tamins region in the Alps (Poschinger et al 2006, Poschinger 2011, Calhoun et al 2015), in the Las Conchas valley in 
Argentina (Hermanns et al 2004), in Chon-Kemin River valley in Northern Tien Shan and in the Naryn and Kokomeren River valleys in the Central Tien in Kyrgyzstan (Strom and Abdrakhmatov 2004, 2009, Strom, 2013). Prehistoric rockslides were found close to the
1949 Khait rock avalanche in Southern Tien Shan in Tajikistan (Leonov 1960, Evans et al 2009b) and near the 1911 Usoi rockslide dam in Pamirs (Fedorenko 1988), though the latter was contested by Ischuk $(2008,2011)$.

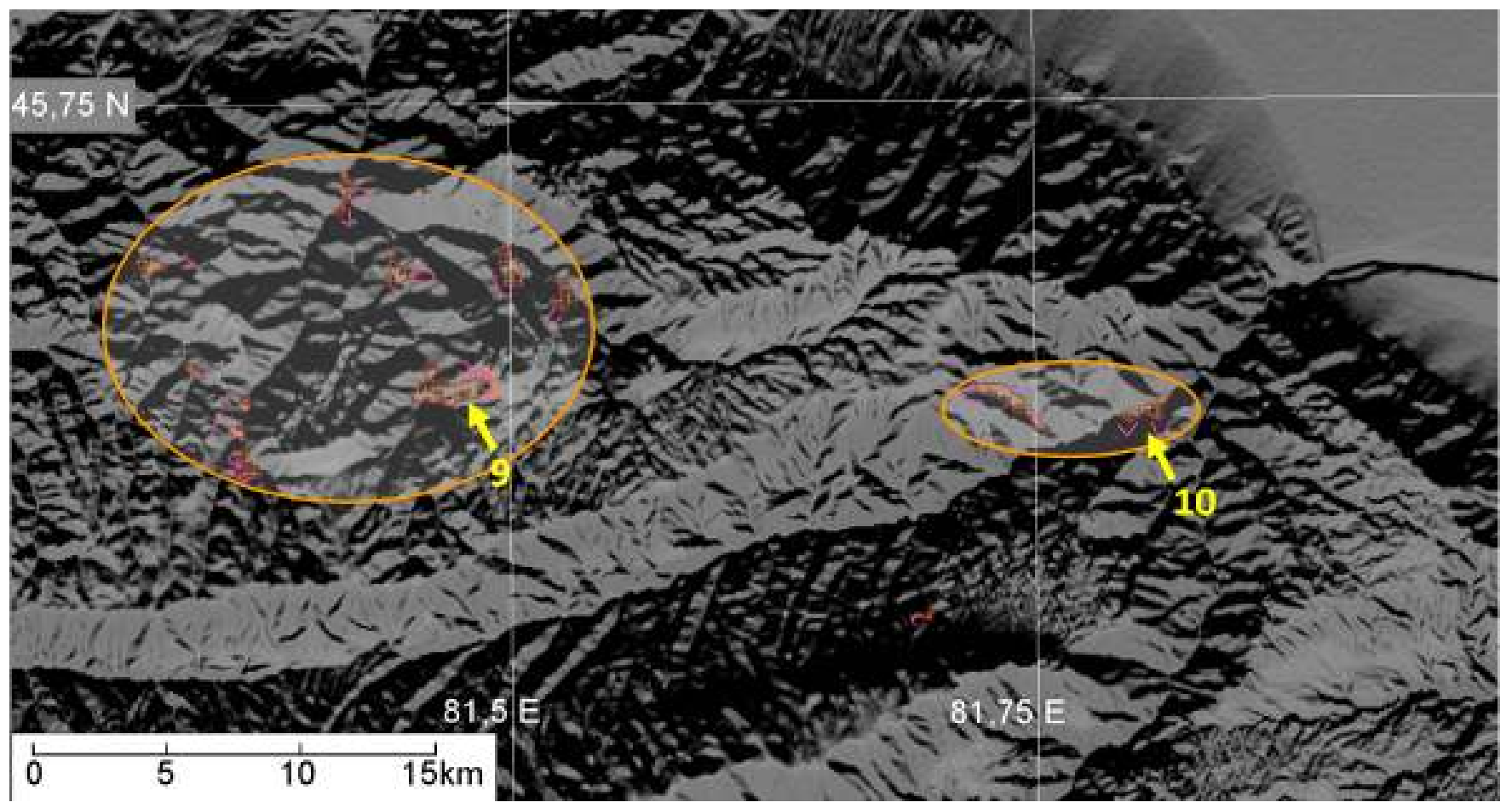

Figure 8. Bedrock landslide clusters (marked by orange ovals) in the northern part of the Djungria Mountains, Southern Kazakhstan. Yellow arrows indicate landslides shown on Figures 9 and 10

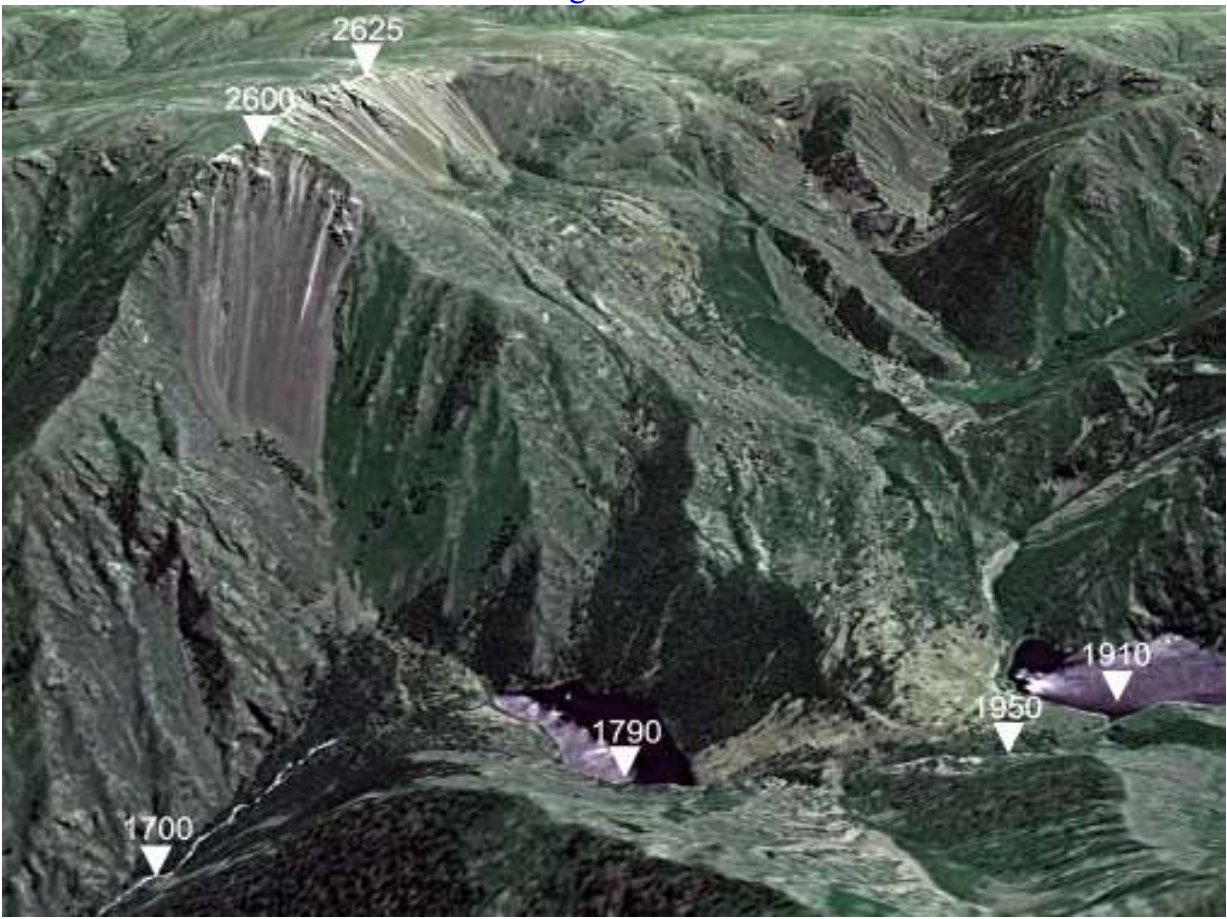

Figure 9. Two river-damming rockslides with similar landscape expressiveness. Numbers show altitudes of the specific geomorphic features. 3D Google Earth image 


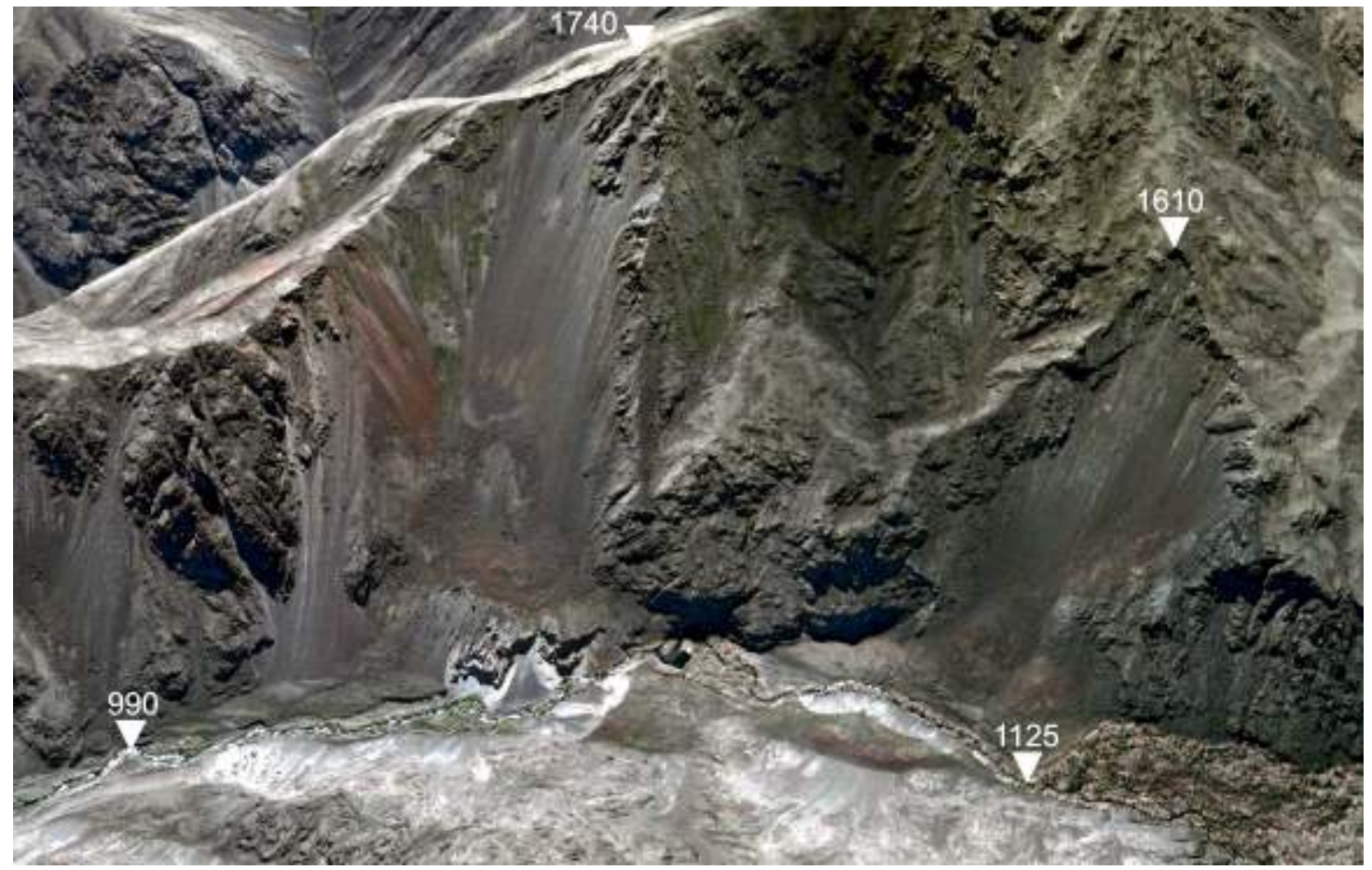

Figure 10. Two deeply eroded rockslide dams resting side-by-side. Numbers show altitudes of the specific geomorphic features. 3D Google Earth image

The distinct non-uniformity of large-scale bedrock landslides spatial distribution raises a question - is it just stochastic or is there something behind, either in the local geology or in the seismicity pattern that had predetermined occurrence of such slope failures in the specific areas in the past and can predetermine it in future.

It can be assumed that spatial clustering of large-scale bedrock landslides is governed by combination of long-term geological, tectonic and geomorphic conditions favourable for slope failures and of short-term triggering factors, both endogenic (large earthquakes) and exogenic (snowmelt, rainstorms and temperature variation). From my point of view it is quite unlikely that their combination could occur randomly just in the same areas several times during time span of tens- and even hundreds of thousands of years. Anyhow, such clusters should be treated as areas of the increased landslide hazard, though it could be difficult to outline with confidence the boundary where such hazard decreases to the 'background' level.

Presence of numerous deep-seated gravitational slope deformations (DSGSD) (Agliardi et al 2001, Crosta et al 2013), at least within some of the clusters described above
(Figure 5) proves higher susceptibility of these areas for future large-scale catastrophic slope failures.

With due consideration of the ambiguity to determine (in general) the exact triggers of largescale bedrock landslides and as far as most of the historical bedrock landslides in the Tien Shan were associated with large $(M>7.0)$ earthquakes, it can be hypothesized that areas where large prehistoric bed-rock landslides concentrate in and had occurred recurrently are more seismically hazardous too. However, confirmation of this assumption is by far more complicated.

Only one (the Aksu) landslide cluster described above is located close to the epicentres of several $\mathrm{Mw}=6.0-6.5$ earthquakes recorded in $60 \mathrm{~s}-70 \mathrm{~s}$ of the $20^{\text {th }}$ Century, while no large earthquake has occurred in the vicinity of other three clusters (Figure 1). Similar discrepancy could be found in the central and western parts of the Tien Shan mountain system (Strom and Abdrakhmatov 2004). It should be pointed out that more or less representative historical data about earthquakes in the Tien Shan - Djungaria region are available for the last 200 years at most, while numerous past large earthquakes in the presently aseismic parts of the region have been 
identified confidently based on paleoseismic data, on the detailed analysis of the Holocene surface ruptures and seismites mainly (e.g., Korjenkov 2006). It is likely that the majority of numerous prehistoric rockslides, including largest of them with more than $1 \mathrm{~km}^{3}$ in volume (Strom and Korup 2006), have been associated with these prehistoric seismic events. However, in most cases except very few of them where it was more or less well grounded (Strom and Stepanchikova 2008, Strom 2012) the detailed complex studies including extensive dating of landslides that group into clusters (see Bull 1996) is necessary to prove or disprove such assumption. Proved realtime simultaneity of nearby rockslides forming clusters could be an ace in the hole to draw such conclusion.

\section{Conclusions}

The distinct concentration of large-scale bedrock landslides within relatively small localized zones of the Tien Shan - Djungaria mountain system along with evidence of their recurrent occurrence and presence of the DSGSDs indicate the increased susceptibility of these zones $20-50 \mathrm{~km}$ (up to ca. $100 \mathrm{~km}$ ) long and up to $20-30 \mathrm{~km}$ wide for catastrophic rock slope failures and, thus, higher landslide hazard in comparison with the surrounding rockslide-free areas. No well-defined peculiarities of the geological structure and geomorphology of such zones could be identified in most cases, which strengthen the assumption that such clustering is caused by long-term spatial constancy of some triggering phenomena.

Since arid climate and limited glaciation makes climate-related triggers unlikely, in the tectonically active Central Asia region, characterized by high seismicity, spatial and temporal clustering of bedrock landslides could be considered as an indicator of large earthquakes repeatedly affecting these zones and, thus, of their increased seismic hazard. However, while higher landslide hazard irrespective of the exact causes/triggers of large-scale slope failures is obvious, the well-founded justification of the increased seismic hazard requires additional studies, first of all, the precise dating of most of slope failures forming such clusters.

\section{Acknowledgement}

I want to express my thanks to the anonymous reviewers whose comments and suggestions helped improving the paper and to Junyan Zhang for correction of the manuscript.

\section{References}

Agliardi, F., G. Crosta and A. Zanchi, 2001. Structural constraints on deep-seated slope deformation kinematics. Engineering Geology, 59: 83 - 102 .

Bogdanovich, K.I., I.M. Kark, B.Y. Korolkov and D.I. Muchketov, 1914. Earthquake of the $4^{\text {th }}$ January 1911 in the northern districts of the Tien Shan. Tr Geol Com Ser 89, 270p. (in Russian).

Bull, W.B., 1996. Prehistorical earthquakes on the Alpine fault, New Zealand. J Geophys Res, 101(B3): 6037 - 6050.

Calhoun, N., A. von Poschinger, J.J. Clague, M. Giardino, D. Masera and L. Perotti, 2015. New Pieces to the Flims-Tamins Rockslide Puzzle. In: Lollino G., D. Giordan, G.B. Crosta, J. Corominas, R. Azzam, J. Wasowski and N. Sciarra (eds), Engineering Geology for Society and Territory, Pros. XII IAEG, Torino 2014, 2: 899 - 903. DOI: 10.1007/978-3-319-09057$3 \_155$

Crosta, G.B., P. Frattini and F. Agliardi, 2013. Deep seated gravitational slope deformations in the European Alps. Tectonophysics, 605: 13 $-33$.

Delaney, K.B. and S.G. Evans, 2015. The 2000 Yigong landslide (Tibetian Plateau), rockslide-dammed lake and outburst flood: review, remote sensing analysis and process modeling. Geomorphology, 246: 377-393.

Delvaux, D., K.E. Abdrakhmatov, I.N. Lemzin and A.L. Strom, 2001. Landslides and surface breaks of the 1911, Ms 8.2 Kemin earthquake, Kyrgyzstan. Russ Geology and Geophysics, 42(10): 1167 - 1177.

Evans, S.G., N.F. Bishop, L.F. Smoll, P.V Murillo, K.B. Delaney and A. Oliver-Smith, 2009a. A reexamination of the mechanism and human impact of catastrophic mass flows originating on Nevado Huascarán, Cordillera 
Blanca, Peru, in 1962 and 1970. Engineering Geology, 108: 96 - 118.

Evans, S.G., N.J. Roberts, A. Ischuck, K.B. Delaney, G.S. Morozova and O. Tutubalina, 2009b. Landslides triggered by the 1949 Khait earthquake, Tajikistan, and associated loss of life. Engineering Geology, 109(3-4): 195 - 212. Fedorenko, V.S., 1988. Rockslides and Rockfalls and Their Prediction. Moscow State University Publishing House, Moscow, 214p. (in Russian). Havenith, H.B., A. Strom, D. Jongmans, K. Abdrakhmatov, D. Delvaux and P. Trefois, 2003. Seismic triggering of landslides, part A: field evidence from the Northern Tien Shan. Natural Hazards and Earth System Sciences, 3: $135-149$.

Hermanns, R.L., S. Niedermann, S. Ivy-Ochs and P.W. Kubik, 2004. Rock avalanching into a landslide dammed lake causing multiple dam failure in Las Conchas valley (NW Argentina) - evidence from surface exposure dating and stratigraphic analyses. Landslides, 1: 113 - 122.

Hewitt, K., 1998. Catastrophic landslides and their effects on the Upper Indus streams, Karakoram Himalaya, Northern Pakistan. Geomorphology, 26: 47 - 80.

Hewitt, K., 2002. Postglacial landform and sediment association in a landslide-fragmented river system: the Transhimalayan Indus streams, Central Asia. In: Hewitt, K. M.L. Byrne, M. English and G. Young (eds), Landscapes of Transition. Kluwer, Dordrecht, $63-91$.

Hewitt, K., 2006. Rock avalanches with complex run out and emplacement, Karakoram Himalaya, Inner Asia. In: Evans, S.G., G.S. Mugnozza, A. Strom and R.L. Hermanns (eds), Landslides from Massive Rock Slope Failure. NATO Science Series: IV: Earth and Environmental Sciences, 49. Springer, Heidelberg, 521 - 550.

Hewitt, K., 2011. Rock avalanche dams on the Trans Himalayan Upper Indus streams: a survey of Late Quaternary events and hazardrelated characteristics. In: Evans, S.G., R.L. Hermanns, A.L. Strom and G. ScarasciaMugnozza (eds), Natural and Artificial Rockslide Dams. Lecture Notes in Earth Sciences, 133. Springer, Heidelberg, 177 - 204p. DOI: 1007/978-3-642-04764-0_6

Hewitt, K., 2015. Massive rock slope failures and episodic landform development generate complex geohazards in the northwest Himalayan syntaxis. In: Lollino, G., D. Giordan, G.B. Crosta, J. Corominas, R. Azzam, J. Wasowski and N. Sciarra (eds), Engineering Geology for Society and Territory, Pros. XII IAEG, Torino 2014, 2. Springer International Publishing Switzerland, 909 - 913.

Ischuk, N.R., 2008. Blockages of river valleys in Tajikistan and their role in assessment of the regional seismicity. In: Proceedings of the $4^{\text {th }}$ International Symposium Geodynamics of the Intracontinental Orogens and Geoecological Problems, Bishkek, Kyrgyzstan, 244 - 245.

Ischuk, N.R., 2011. The Role of glacial deposits in forming modern mountain lake dams in the Pamirs. Georisk, 1: 16 - 29 (in Russian).

King, J., I. Loveday and R.L. Schuster, 1989. The 1985 Bairaman landslide dam and resulting debris flow, Papua New Guinea. Q. J. Engineering Geology, 22: 257 - 270.

Korjenkov, A.M., 2006. Seismogeology of the Tien Shan (within the limits of the Kyrgyztan and ajacent regions). Bishkek, Ilim, 289p. (in Russian).

Korjenkov, A.M., E. Mamyrov, M. Omuraliev, V.A. Kovalenko and S.F. Usmanov, 2004. Rock avalanches and landslides formed in result of strong Suusamyr (1992, M = 7.4) earthquake in the Northern Tien Shan - test structures for mapping of paleoseismic deformations by satellite images. In: Buchroithner, M.F. (ed), High Mountain Remote Sensing Cartography VII (HMRSC VII). Kartographische Bausteine, Band 23, Dresden, 117 - 136.

Leonov, N.N., 1960. The 1949 Khait earthquake and geological conditions of its occurrence. In: Proceedings of Russian Academy of Sciences, Geophysical Series, No 3, 409 - 424 (in Russian).

Leonov, N.N., 1970. The 1946 Chatkal earthquake. Problems of the Engineering Seismology, 13: 64 - 77. (in Russian).

Malamud, B.D., D.L. Turcotte, F. Guzzetti and P. Reichenbach, 2004. Landslides, earthquakes and erosion. Earth Planet Science Letters, 229: 
$45-59$.

Mushketov, I.V., 1890. The Vernyi earthquake of 28/05 (9/06) 1887. In: Proceedings of Geological Committee, 10(1). St. Petersburg, 154p. (in Russian).

Neshikhovskiy, R.A., 1988. Floods on rivers and lakes. Hydrometeoizdat, Leningrad, 184p. (in Russian).

Plafker, G. and G.E. Eriksen, 1978. Nevados Huascaran avalanches, Peru. In: Voight, B. (ed), Rockslides and Avalanches, 1. Elsevier, Amsterdam, 277 - 314.

Poschinger, A. von., 2011. The Flims Rockslide Dam. In: Evans, S.G., R.L. Hermanns, A.L. Strom and G. Scarascia-Mugnozza (eds), Natural and Artificial Rockslide Dams. Lecture Notes in Earth Sciences, 133. Springer, Heidelberg, 407 - 421. DOI: 1007/978-3-64204764-0 15

Poschinger, A. von, P. Wassmer and M. Maisch, 2006. The Flims rockslide: history of interpretation and new insights. In: Evans, S.G., G.S. Mugnozza, A. Strom and R.L. Hermanns (eds), Landslides from Massive Rock Slope Failure. NATO Science Series IV: Earth and Environmental Sciences, 49. Springer, Heidelberg, 329 - 356.

Shang, Y., Z. Yang, L. Li, D. Liu, Q. Liao and Y. Wang, 2003. A super-large landslide in Tibet in 2000: background, occurrence, disaster, and origin. Geomorphology, 54: 225 - 243.

Strom, A.L., 2012. Use of indirect evidence for the prehistoric earthquake-induced landslides identification. In: Ugai, K., H. Yagi and A. Wakai (eds), Earthquake-induced Landslides. Proceedings of the International Symposium on Earthquake-induced Landslides. Kiryu, Japan, 21 - 30. DOI: 10.1007/978-3-64232238-9 3

Strom, A., 2013. Geological prerequisites for landslide dams' disaster assessment and mitigation in Central Asia. In: Wang, F., M. Miyajima, T. Li, W. Shan and T.F. Fathani (eds), Progress of Geo-Disaster Mitigation Technology in Asia, Environmental Science and Engineering, Springer-Verlag Berlin Heidelberg, 17 - 53. DOI: 10.1007/978-3-64229107-4 2

Strom, A.L. and K.E. Abdrakhmatov, 2004. Clustering of large rockslides: the phenomenon and its possible causes. In: Lacerda, W.A., M. Ehrlich, A.B. Fontoura and A. Sayao (eds), Landslides: Evaluation and Stabilization. Taylor \& Francis Group, London, $317-320$.

Strom, A.L. and K.E. Abdrakhmatov, 2009. International summer school on rockslides and related phenomena in the Kokomeren River valley, Tien Shan, Kyrgyzstan. In: Sassa, K. and P. Canuti (eds), Landslide Disaster Risk Reduction. Springer, Berlin, 223 - 227.

Strom, A.L. and O. Korup, 2006. Extremely large rockslides and rock avalanches in the Tien Shan, Kyrgyzstan. Landslides 3: 125 -136.

Strom, A.L. and P. Stepanchikova, 2008. Seismic triggering of large prehistoric rockslides: pro and con case studies. In: Proceedings of the International Conference on Management of Landslide Hazard in the Asia-Pacific Region. Satellite Symposium of the First World Landslide Forum, 202 - 211. 